DedikasiMU (Journal of Community Service)

Volume 2, Nomor 1, Maret 2020

\title{
PSIKOEDUKASI MENGGUNAKAN METODE SIMULASI GAME PERKEMBANGAN ANAK
}

\author{
Syaiful Huda1, Andi Rahmad Rahim², Muhammad Ridlwan ${ }^{3}$, Dian Anita $S^{4}$ \\ ${ }^{1}$ Dosen Program Studi Pendidikan Matematika, Universitas Muhammadiyah Gresik \\ ${ }^{2}$ Dosen Program Studi Akuakultur, Universitas Muhammadiyah Gresik \\ ${ }^{3,4}$ Mahasiswa Program Studi Psikologi, Universitas Muhammadiyah Gresik \\ Email: muh.ridlwan012@gmail.com, nitadian110@gmail.com
}

\begin{abstract}
ABSTRAK
Ngampel adalah sebuah desa yang terletak di Balongpanggang, Gresik. Yang dibatasi oleh Lamongan di Sebelah Utara,Mojokerto di Sebelah Selatan, Desa Tanah Landehan di Sebelah Timur, dan Desa Brangkal di Sebelah Barat. Luas lahan desa Ngampel adalah $172 \mathrm{Ha}$, yang terdiri dari $138 \mathrm{Ha}$ lahan pertanian dan lainnya adalah pemukiman, sekolah, tempat ibadah, balai desa, dan lainnya. Jumlah penduduk di desa ini adalah 1.725 orang, dengan mayoritas mata pencaharian adalah Petani. Desa Ngampel memiliki Lembaga Pendidikan berupa 2 Sekolah Tingkat Dasar dan 2 Tingkat TK dan Paud. Untuk mencapai tujuan yang diharapkan, program KKN di desa ngampel, dilakukan dengan pemberdayaan siswa tingkat dasar mengenai pentingnya pengetahuan dan kesiapan tentang perkembangan individu, dalam program yang diberikan oleh mahasiswa KKN Prodi Psikologi dengan menggunakan simulasi Game Snake and Leader yang telah dimodifikasi menggunakan aspek-aspek psikologi perkembangan anak.
\end{abstract}

Kata Kunci: PsikoEdukasi, Simulasi Game, Perkembangan Anak, Desa Ngampel. 


\section{PENDAHULUAN}

\section{A. Latar Belakang}

Secara geografis, Desa Ngampel terletak di wilayah Kecamatan Balongpanggang, Kabupaten Gresik. Lokasi Desa Ngampel ini berbatasan oleh Lamongan di Sebelah Utara Mojokerto di Sebelah Selatan, Desa Tanah Landehan di Sebelah Timur, dan Desa Brangkal di Sebelah Barat.

Desa Ngampel terdiri dari dari 2 Dusun, yakni Dusun Karangpilang dan Dusun Kedondong. Secara umum mata pencaharian warga masyarakat Desa Prupuh dapat terindentifikasi ke dalam beberapa sektor yaitu petani, peternak, pengrajin kayu, buruh pabrik, PNS, Guru dan polisi.

Dalam ranah pendidikan, Desa Ngampel memiliki 4 lembaga pendidikan yang terdiri dari SD, MI, TK, dan Paud. Masing - masing dusun memiliki 1 sekolah tingkat dasar dan satu lembaga TK atau Paud. Jumlah siswa yang tingkat sekolah dasar sebanyak 61 siswa di SDN Ngampel dan 39 siswa di MI Ngampel.

mahasiswa program studi Psikologi melakukan Program Kerja Psiko Edukasi dengan menggunakan simulasi game tentang perkembangan dengan konsep snake and leader, game ini dilakukan oleh siswa tingkat SD dengan jumlah maksimal 5 orang, mahasiswa memberikan aturan main pada siswa sebelum melakukan permainan, dalam penilainnya game ini menggunakan metode observasi dikelas dan wawancara berasama guru, konsep game ini terdiri dari aspek perkembangan Konsep Diri, Kreatifitas, Bahasa, Moral, Sosial dan kepercayaan diri. Game ini juga menggunakan konsep stimulus respon dan menggunakan sistem rangking pada hasil permainan. setelah permainan selesai mahasiswa melakukan wawancara kepada guru tentang kelebihan dan kekurangan setiap individu yang mengikuti simulasi ini. dan mahasiswa memberikan solusi terhadap sekolah agar anak yang dirasa kesulitan dalam beberapa aspek agar diberi perlakuan khusus dalam menididiknya.

\section{B. Tujuan}

Adapun tujuan dari program kerja "Psikoedukasi Menggunakan Metode Simulasi Game Perkembangan Anak" di desa Ngampel Kecamatan Balongpanggang Kabupaten Gresik, yaitu Siswa Mampu pengeksplorasi dirinya serta meningkatkan 


\section{DedikasiMU (Journal of Community Service)}

Volume 2, Nomor 1, Maret 2020

pengetahuan dan perkembangan dalam aspek perkembangan kreativitas, sosial, komunikasi, akademik serta kepercayaan diri siswa.

\section{METODE PELAKSANAAN}

Untuk mencapai tujuan yang diharapkan, program KKN di desa ngampel, dilakukan dengan pemberdayaan siswa tingkat dasar mengenai pentingnya pengetahuan dan kesiapan tentang perkembangan individu, dalam program yang diberikan oleh mahasiswa KKN Prodi Psikologi dengan menggunakan simulasi Game Snake and Leader yang telah dimodifikasi menggunakan aspek-aspek psikologi perkembangan anak. Adapun ringkasan metode pelaksanaan yang dilakukan pada Sabtu, 14 September dan Sabtu, 19 Oktober 2019 beserta jam kerja efektif mahasiswa tersaji pada tabel berikut :

Tabel 1. Susunan Pelaksanaan Kegiatan

\begin{tabular}{|c|c|c|c|c|c|}
\hline No. & $\begin{array}{l}\text { Susunan } \\
\text { Kegiatan }\end{array}$ & Kegiatan & Waktu & $\begin{array}{l}\text { Jumlah } \\
\text { Peserta }\end{array}$ & $\begin{array}{c}\text { Lokasi } \\
\text { Kegiatan }\end{array}$ \\
\hline \multirow[t]{6}{*}{1} & \multirow[t]{6}{*}{ Pembukaan } & \multirow{6}{*}{$\begin{array}{c}\text { Mahasiwa menyampaikan } \\
\text { Tujuan dan aturan } \\
\text { bermain game kepada } \\
\text { siswa tingkat Dasar }\end{array}$} & \multirow{6}{*}{$\begin{array}{c}10 \\
\text { Menit }\end{array}$} & 5 & \multirow{4}{*}{$\begin{array}{l}\text { Ruang Kelas } \\
\text { SDN Ngampel }\end{array}$} \\
\hline & & & & Siswa & \\
\hline & & & & 5 & \\
\hline & & & & Siswa & \\
\hline & & & & 4 & Ruang Kelas MI \\
\hline & & & & Siswa & Ngampel \\
\hline \multirow[t]{6}{*}{2} & \multirow[t]{6}{*}{ Praktek } & \multirow{6}{*}{$\begin{array}{l}\text { Memulai permaianan } \\
\text { simulasi snake \& leader }\end{array}$} & \multirow{6}{*}{$\begin{array}{c}85 \\
\text { Menit }\end{array}$} & 5 & \multirow{4}{*}{$\begin{array}{l}\text { Ruang Kelas } \\
\text { SDN Ngampel }\end{array}$} \\
\hline & & & & Siswa & \\
\hline & & & & 5 & \\
\hline & & & & Siswa & \\
\hline & & & & 4 & Ruang Kelas MI \\
\hline & & & & Siswa & Ngampel \\
\hline \multirow[t]{6}{*}{3} & \multirow{6}{*}{$\begin{array}{c}\text { Pemberian } \\
\text { Reward }\end{array}$} & \multirow{6}{*}{$\begin{array}{c}\text { Memberikan Reward } \\
\text { Pada siswa yang berhasil } \\
\text { mencapai Finish terlebih } \\
\text { dahulu }\end{array}$} & \multirow[t]{6}{*}{5 Menit } & 5 & \multirow{4}{*}{$\begin{array}{l}\text { Ruang Kelas } \\
\text { SDN Ngampel }\end{array}$} \\
\hline & & & & Siswa & \\
\hline & & & & 5 & \\
\hline & & & & Siswa & \\
\hline & & & & 4 & Ruang Kelas MI \\
\hline & & & & Siswa & Ngampel \\
\hline
\end{tabular}


DedikasiMU (Journal of Community Service)

Volume 2, Nomor 1, Maret 2020

\begin{tabular}{|c|c|c|c|c|c|}
\hline \multirow[t]{2}{*}{4} & \multirow[t]{2}{*}{ Evaluasi } & \multirow{2}{*}{$\begin{array}{l}\text { Mahasiswa Memberikan } \\
\text { feadback kepada guru } \\
\text { mengenai situasi dan } \\
\text { kondisi siswa yang ikut } \\
\text { serta dalam permainan } \\
\text { ini. }\end{array}$} & \multirow[t]{2}{*}{$\begin{array}{c}20 \\
\text { Menit }\end{array}$} & 2 Guru & $\begin{array}{c}\text { Ruang Guru } \\
\text { SDN Ngampel }\end{array}$ \\
\hline & & & & 1 Guru & $\begin{array}{c}\text { Ruang Guru MI } \\
\text { Ngampel }\end{array}$ \\
\hline
\end{tabular}

\section{A. Ruang Lingkup / Object}

Ruang lingkup program kerja ini dilakukan di Desa Ngampel tepatnya di SDN Ngampel Dusun Karangpilang dan MI Ngampel di Dusun Kedondong.

\section{B. Waktu dan Tempat Kegiatan}

Adapaun nama kegiatan, tempat dan waktu pelaksanaan disajikan dalam tabel berikut.

Tabel 2. Waktu dan Tempat Pelaksanaan.

\begin{tabular}{|c|c|c|}
\hline Nama Kegiatan & Tempat & Waktu \\
\hline \multirow{2}{*}{ Observasi } & SDN Ngampel & Sabtu, 10 Agustus 2019 \\
\hline & MI Ngampel & Sabtu, 31 Agustus 2019 \\
\hline $\begin{array}{c}\text { Pembuatan Konsep dan } \\
\text { peralatan Game. }\end{array}$ & $\begin{array}{c}\text { Universitas } \\
\text { Muhammadiyah Gresik }\end{array}$ & $02-12$ September 2019 \\
\hline \multirow[t]{2}{*}{ Praktek } & SDN Ngampel & $\begin{array}{c}\text { Sabtu, 14 September } \\
2019\end{array}$ \\
\hline & MI Ngampel & Sabtu, 19 Oktober 2019 \\
\hline
\end{tabular}

\section{Teknik Pengumpulan Data}

Teknik pengumpulan data yang dilakukan oleh mahasiswa yaitu dengan cara Observasi Murid dan wawancara langsung kepada pihak guru disekolah untuk mengetahui kondisi yang dihadapi oleh siswa sekolah dasar.

\section{HASIL DAN PEMBAHASAN}

\section{A. Hasil}

Game Simulasi Perkembangan menggunakan Konsep Permainan Snake and Leader yang sudah dimodifikasi dengan menggunakan teori psikologi perkembangan. Adapun teori yang digunakan dalam permainan ini mencangkup tentang perkembangan perilaku, Kreativitas, Bahasa, Moral, Minat Bakat, kepribadian. 


\section{DedikasiMU (Journal of Community Service)}

Volume 2, Nomor 1, Maret 2020

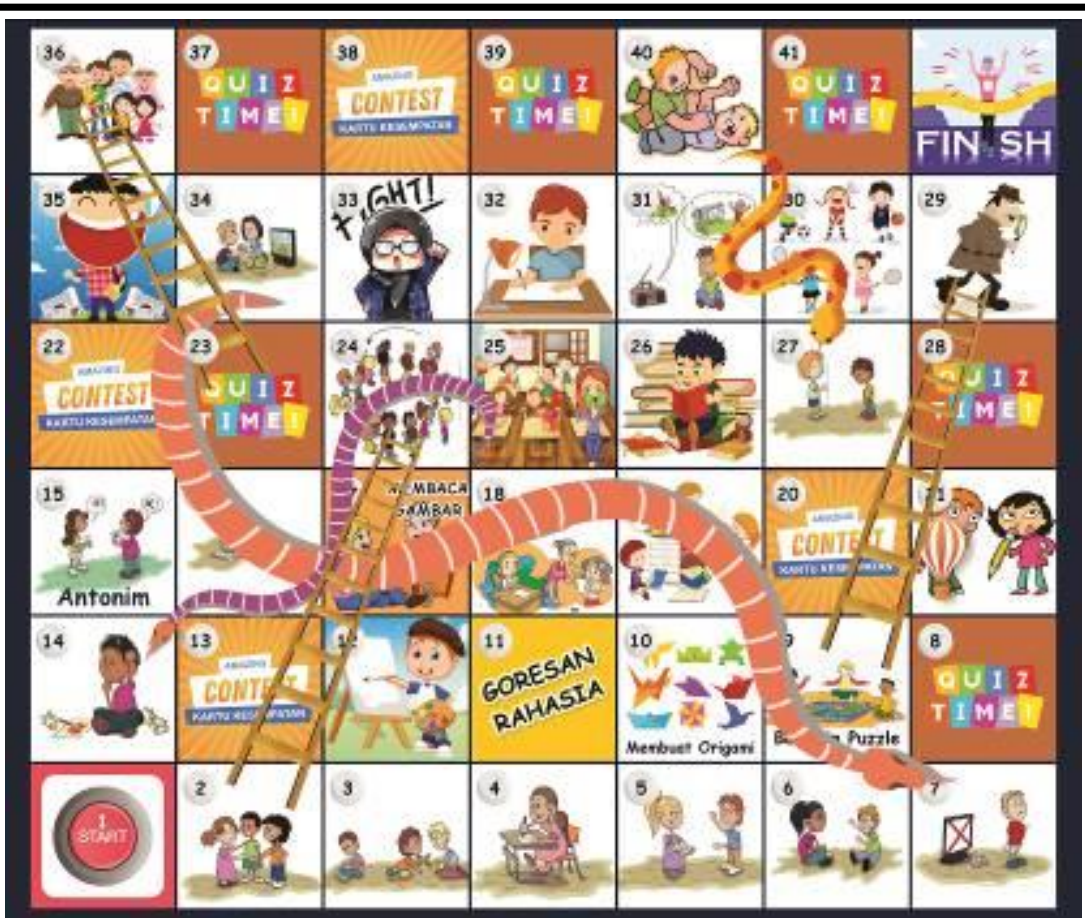

Gambar 1. Tampilan Game Simulasi Perkembangan

\section{- Aturan dan Cara Bermain}

1. Tentukan Jumlah Pemain sebanyak 5 orang, kemudian tentukan urutan pemain dengan cara diundi (misalnya dengan cara hompimpah atau suit)

2. Pemain pertama melempar dadu, lihat angka yang muncul kemudian melangkah mulai dari kotak pertama, sebanyak angka yang muncul tersebut

3. Bila pemain melempar dadu muncul angka 2 maka jumlah langkah yang harus dilakukan adalah $6+2$, baru diberi pertanyaan. bila lemparan ke dua muncul angka 6 kembali, maka tidak melempar dadu lagi, jumlah angka yang harus dilakukan adalah $6+6$ dan diberi pertanyaan.

4. Bila permain bisa menjawab pertanyaan dengan benar maka mendapatkan kesempatan melempar dadu lagi dan pemain melangkah sesuai dengan jumlah angka yang muncul.

5. permain yang tidak menjawab pertanyaan atau jawabannya salah, maka pemain tersebut tetap berada pada kotaknya.

6. Pertanyaan yang tidak bisa dijawab maka diberikan kesempatan kepada penonton (Kelompoknya) untuk membantu menjawab.

7. Bila permainan berhenti pada kotak bergambar panah putih, maka pemain naik sampai kotak ujung panah, bila pemain berhenti pada kotak bergambar panah merah, maka pemain turun sampai kotak ujung panah merah. 


\section{DedikasiMU (Journal of Community Service)}

Volume 2, Nomor 1, Maret 2020

8. pemain dilanjutkan oleh pemain berikutnya dengan melempar dadi dan mulai dari kotak pertama pemain menyelesaikan permainan apabila telah mencapai kotak terakir.

9. seluruh permainan berakhir apabila semua pemain telah mencapai kotak terakhir atau batas waktu yang sudah ditentukan fasilitator.

10. peringkat pemenang sesuai dengan urutan permainan yang mencapai kotak terakhir

11. permainan dapat diulang kembali dengan pemain yang baru.

12. Catatan : Permainan bisa dilakukan dalam bentuk tim, yang 1 tim berisi 1 pemain dan 2-3 pembantu atau bisa dilakukan solo dengan minimal anggota 5 orang

\section{- Alat Pendukung}

1. Banner Ular tangga Uk 300x200 Cm

7. Krayon

2. Kertas Hvs A4

8. Pensil

3. Buku Cerita

9. Kartu Kesempatan

4. Buku Gambar

10. Ilustrasi

5. Krayon

11. Puzzle

6. Origami

12. Kartu Perintah

\section{- Landasan Teori}

Perkembangan Peserta Didik merupakan suatu komponen penting yang harus diketahui seorang guru. Pemahaman guru yang benar terhadap perkembangan peserta didik akan menuntun guru membuat disain pembelajaran yang cocok untuk peserta didik. Disain pembelajaran yang cocok dengan perkembangan peserta didik akan menghasilkan pembelajaran yang maksimal. Pembelajaran yang tidak memperhatikan perkembangan peserta akan membuat peserta bosan atau frustrasi. Jika peserta didik bosan dan frustrasi, para guru juga akan tertular rasa bosan dan frustrasi ketika mengajar. Dasar pikir ini yang menjadikan pengetahuan tentang perkembangan peserta didik merupakan salah satu komponen dari kompetensi pedagogik seorang guru.

Mengingat hal diatas Program Kerja game siumlasi perkembangan ini menjadi perlu untuk dilakukan supaya siswa mampu meningkatkan pengetahuan mengenai perkembangan individu dan akademik siswa. Di dalam teori behaviour (perilaku) lebih menekankan jika kognisi tidak penting ketika memahami perilaku. Menurut B.F Skinner yang merupakan pakar behaviouris ternama, perkembangan merupakan perilaku yang dapat diamati serta ditentukan oleh hadiah atau hukuman yang didapatkan dari lingkungan. 


\section{DedikasiMU (Journal of Community Service)}

Volume 2, Nomor 1, Maret 2020

Sedangkan dalam teori belajar sosial yang dikembangkan Albert Bandura dkk, meskipun proses kognitif sangat lah penting namun lingkungan menjadi faktor yang paling penting dalam mempengaruhi perilaku individu. Di dalam teori ini, menjelaskan jika manusia memiliki kemampuan dalam mengendalikan tingkah lakunya sendiri. Di dalam teori behaviour sendiri terdapat 3 versi yaitu Pavlov dan kondisioning klasik, Skinner dengan kondisioning operant, serta bandura dengan teori belajar social

Dalam Teori Kreativitas Menurut kamus Webster dalam Anik Pamilu (2007:9) kreativitas adalah kemampuan seseorang untuk mencipta yang ditandai dengan orisinilitas dalam berekspresi yang bersifat imajinatif. Dalam Kamus Besar Bahasa Indonesia, kreativitas adalah kemampuan untuk mencipta, perihal berkreasi dan kekreatifan.

Dalam Teori Perkembangan Bahasa, Menurut Skinner (1957), memandang perkembangan bahasa dari sudut stimulus-respon, yang memandang berpikir sebagai proses internal bahasa mulai diperoleh dari interaksi dalam lingkungan. Bandura, (1997) memandang perkembangan bahasa dari sudut teori belajar sosial.

Teori moral adalah sikap dan perilaku individu yang didasari oleh nilai nilai hukum yang berada di lingkungan tempat dia hidup. Jadi individu dapat dikatakan dapat memiliki teori moral adalah ketika individu sudah hidup dengan mentaati hukum hukum yang berlaku di tempat dia hidup.

Sedangkan menurut Lawrence Kohlberg, tahapan perkembangan teori moral adalah ukuran dari tinggi rendahnya teori moral individu berdasarkan perkembangan penalaran teori moralnya. Teori perkembangan moral kohlberg yang dikemukakan oleh Psikolog Kohlberg menunjukan bahwa perbuatan moral bukan hasil sosialisasi atau pelajaran yang diperoleh dari kebiasaan dan hal hal lain yang berhubungan dengan norma kebudayaan (Sunarto,2013:176)

Menurut Sukardi (1994:83) bahwa minat merupakan salah satu unsur kepribadian yang memegang peranan penting dalam mengambil keputusan masa depan. Minat mengarahkan individu terhadap suatu obyek atas dasar rasa senang atau rasa tidak senang. Perasaan senang atau tidak senang merupakan dasar suatu minat. Minat seseorang dapat diketahui dari pernyataan senang atau tidak senang terhadap suatu obyek tertentu. 


\section{B. Pembahasan}

Target yang dicapai siswa mampu menyelesaikan permainan dengan tingkat yang berbeda, setiap siswa mampu menunjukkan kemampuannya dalam Aspek perkembangan yang dituju, dan Mahasiswa $(\mathrm{KKN})$ mampu mengenali permasalahan yang ada disetiap individu maupun sosial di kelas dengan menggunakan Observasi dan wawancara kepada Guru.

Hambatan : beberapa siswa mengalami dalam hambatan dalam kepercayaan diri dan akademik, hingga mereka tidak mampu untuk menyelesaikan persoalan atau perintah yang ada disetiap langkah yang diambil, serta kondisi kelas yang begitu ramai dan sulit diatur membuat permainan menjadi lebih lama.

Solusi : setelah permainan selesai Mahasiswa KKN menjumpai Guru Wali dikelas yang kami lakukan treatmen dan memberikan feadback bahwa pada siswa yang mengikuti permainan ini, karena ada beberapa siswa yang benar benar perlu diberikan bimbingan khusus karena kemampuannya kurang bagus dibanding teman sesuianya.

\section{KESIMPULAN DAN SARAN}

\section{A. Kesimpulan}

Berdasarkan hasil yang didapat dalam program kerja psikologi ini, maka dapat ditarik kesimpulan sebagai berikut :

1. Menghasilkan game simulasi perkembangan yang dapat menyajikan materi dan pertanyaan sebagai evaluasi.

2. Game simulasi perkembangan ini dapat menjadi sarana alternatif untuk menunjang pembelajaran dan perilaku siswa.

3. Hasil observasi menunjukan dengan menggunakan game simulasi perkembangan yang menarik, sehingga peserta merasa senang dengan pembelajaran dan konsep perkembangan siswa.

\section{B. Saran}

Disarankan pada Guru agar memberikan bimbingan khusus kepada beberapa siswa yang memiliki keterbatasan dalam perkembangan dalam perkembangan perilaku, Kreativitas, Bahasa, Moral, Minat Bakat, kepribadian, yang khususnya pada bidang Akademik dan kepercayaan diri individu.

Dari semua hasil penelitian dan implementasi yang telah dicapai saat ini, game simulasi ini masih mempunyai beberapa kekurangan. Untuk membuat aplikasi ini lebih baik lagi, disarankan pengembangan aplikasi lebih lanjut diantaranya : 


\section{DedikasiMU (Journal of Community Service)}

Volume 2, Nomor 1, Maret 2020

1. Perlunya merevisi beberapa perintah yang ada didalam game yang dirasa kurang menarik peserta.

2. Mengevaluasi kembali level permainan disetiap tingkatan sekolah.

3. Perlunya penerapan tingkatan kepribaidan yang lebih kompleks sehingga game menjadi lebih mudah dipahami.

\section{DAFTAR PUSTAKA}

Hurlock, Elizabeth B., (2002). Psikologi Perkembangan. Jakarta : Erlangga edisi kelima Kamus besar bahasa Indonesia, 2002 : 1118

Martani Wisnu. (2012). Metode Stimulasi dan Perkembangan Emosi Anak Usia Dini. Jurnal Psikologi.Vol.39 No.1.

Rahim A.R, Bela ND, Mutmainnah M, Araswati Z. (2019). Sosialisasi Dan Implementasi Pembuatan Krupuk Ikan Bandeng Desa Karanggeneng Kec. Karanggeneng Kab. Lamongan. Jurnal DedikasiMU. Vol 1. No 1. pp 1-10.

Rahim A.R. (2018) Pemanfaatan Limbah Tambak Ikan Untuk Budidaya Cacing Tanah Lumbricus rubellus. Jurnal Perikanan Pantura (JPP). Vol 2. No 1. pp. 1-8.

Rahim A.R. (2018). Application of Seaweed Gracilaria verrucosa Tissue Culture using Different Doses of Vermicompost Fertilizer. Nature Environment and Pollution Technology. Vol 17. pp.661-665.

Rahim A.R., Herawati E.Y., Nursyam H., Hariati AM. (2016). Combination of Vermicompost Fertilizer, Carbon, Nitrogen and Phosphorus on Cell Characteristics, Growth and Quality of Agar Seaweed Gracilaria verrucosa. Nature Environment \& Pollution Technology. Volume 15, No. 4.

Rahim A.R., Ruhumuddin S, Rosmarlinasiah. (2019). Productivity Improvement of Milkfish and Seaweed Polyculture using Vermicomposting Fertilizer from Sources of Waste. International Journal of Recent Technology and Engineering. Volume-8 Issue-3. pp 1377-1381.

Santrock, John W. (2002). Life-span Development : Perkembangan Masa Hidup. Edisi 5 jilid 2, Jakarta : Erlangga.

Yusup, Syamsu. (2005). Psikologi Perkembangan Anak dan Remaja, Bandung. PT Remaja Rosda karya,2005. 